\title{
Recombinant expression and characterization of a cysteine peptidase from Xanthomonas citri subsp citri
}

\author{
A. Soares-Costa ${ }^{1 *}$, R.S. Silveira ${ }^{1 *}$, M.T.M. Novo ${ }^{2}$, M.F.M. Alves ${ }^{3}$, \\ A.K. Carmona ${ }^{3}$, J. Belasque $\mathrm{Jr}^{4}{ }^{4}$ and F. Henrique-Silva ${ }^{1}$ \\ ${ }^{1}$ Laboratório de Biologia Molecular, Departamento de Genética e Evolução, \\ Universidade Federal de São Carlos, São Carlos, SP, Brasil \\ ${ }^{2}$ Laboratório de Bioquímica e Biologia Molecular de Microrganismos, \\ Departamento de Genética e Evolução, Universidade Federal de São Carlos, \\ São Carlos, SP, Brasil \\ ${ }^{3}$ Departamento de Biofísica, Universidade Federal de São Paulo, \\ São Paulo, SP, Brasil \\ ${ }^{4}$ Fundo de Defesa da Citricultura, Araraquara, SP, Brasil \\ *These authors contributed equally to this study. \\ Corresponding author: F. Henrique-Silva \\ E-mail: dfhs@ufscar.br
}

Genet. Mol. Res. 11 (4): 4043-4057 (2012)

Received July 26, 2012

Accepted November 8, 2012

Published November 28, 2012

DOI http://dx.doi.org/10.4238/2012.November.28.3

ABSTRACT. Xanthomonas citri subsp citri (Xac) is the bacterium responsible for citrus canker disease in citrus plants. The aim of this study was to describe the recombinant expression, purification, and characterization of a cysteine peptidase from Xac strain 306, which is a candidate for involvement in the pathogenicity of this bacterium. The gene was cloned and expressed in Pichia pastoris, and the cysteine peptidase was successfully expressed, secreted, and purified using affinity chromatography with a yield of approximately $10 \mathrm{mg} / \mathrm{L}$. A polyclonal antibody produced against cysteine peptidase from $X$. citri subsp citri fused with HIS tag $\left(_{H I S}\right.$ CPXAC) recognized the purified 
recombinant cysteine peptidase ${ }_{H I S}$ CPXAC, confirming the correct production of this protein in $P$. pastoris. The same antibody detected the protein in the culture supernatant of Xac grown in pathogenicityinducing medium. Kinetic analysis revealed that ${ }_{H I S} \mathrm{CPXAC}$ hydrolyzed the carbobenzoxy-Leu-Arg-7-amido-4-methylcoumarin substrate with a catalytic efficiency $\left(k_{\text {cat }} / K_{\mathrm{m}}\right)$ of $47 \mu \mathrm{M}^{-1} \cdot \mathrm{s}^{-1}$. The purified ${ }_{H I S} \mathrm{CPXAC}$ displayed maximal catalytic activity at $\mathrm{pH} 5.5$ and $30^{\circ} \mathrm{C}$. The recombinant enzyme was inhibited by the specific cysteine peptidase inhibitor E-64, as well as by the recombinant cysteine peptidase inhibitors CaneCPI-1, CaneCPI-2, CaneCPI-3, and CaneCPI-4, with $\mathrm{K}_{\mathrm{i}}$ values of 1.214 , 84.64, 0.09, 0.09, and $0.012 \mathrm{nM}$, respectively. Finally, the N-terminal sequencing of the purified protein enabled the identification of the first 5 amino acid residues (AVHGM) immediately after the putative signal peptide, thereby enabling the identification of the cleavage point and corroborating previous studies that have identified this sequence in a secreted protein from Xanthomonas spp.

Key words: Cysteine peptidase; Xanthomonas citri subsp citri; Pichia pastoris; Recombinant expression

\section{INTRODUCTION}

Citrus production is important in Brazilian agriculture, and the industry focuses on large-scale production for the exportation of orange juice. A number of factors, such as losses caused by pathogens, can affect citrus productivity. The Gram-negative bacterium Xanthomonas citri subsp citri $(\mathrm{Xac})$ is a citrus pathogen that causes economic losses worldwide (Viegas and Machado, 2006). Three types of citrus canker pathogens (A, B, and C) are described in the literature. Type A originated in Asia and is the most widespread, causing the greatest economic damage (Schubert and Miller, 1996). The other types are found only in South America. The causal agent of canker A is Xac, which causes disease in several citrus species, including Citrus paradisi (grapefruit) and Citrus aurantifolia (Mexican lime), which are the most susceptible fruits in the field, as well as Citrus reticulata (mandarin/tangerine) and Citrus sinensis (sweet orange), which are relatively tolerant and less susceptible, respectively (Gabriel et al., 1988). Citrus canker disease is characterized by the formation of dark, circular, raised, blister-like, water-soaked lesions with a spongy appearance and rough surface. The bacteria infect stems, leaves, and fruit, leading to defoliation, twig dieback, and premature dropping of fruit (Graham et al., 2004; Dalla Pria et al., 2006). The pathogen penetrates the plant through natural openings (stomata) and injuries, colonizing the intercellular space in the apoplast and breaking down the leaf epidermis as a result of cell hyperplasia (Brunnings and Gabriel, 2003).

The genome of Xac strain 306 has been sequenced (Da Silva et al., 2002) and compared to the genomes of bacteria from the family Xanthomonadaceae that are pathogenic in other plants (Moreira et al., 2005). However, biochemical characterization of the proteins involved in the pathogenicity of Xac strain 306 remains scarce. Particular attention has been paid to extracellular peptidases owing to their possible role in bacterial pathogenesis and their usefulness as molecular targets for understanding and controlling diseases. Yamazaki et al. 
(2008) have identified several proteins secreted from Xanthomonas pv. citri NA-1 cultivated under conditions conducive for the induction of hrp and hypersensitivity genes, which may be related to pathogenicity and the infection process. One of the proteins identified from $X$. pv. citri NA-1 is an extracellular cysteine peptidase. Extracellular cysteine peptidases may contribute to the infection process by disrupting plant tissue and allowing the spread of bacteria throughout the vascular system (Nogaroto et al., 2006).

Peptidases fulfill a large variety of physiological functions, and their importance in metabolic and regulatory functions is evident by their presence in all forms of biological systems, from viruses to vertebrates (Turk et al., 2000; Potempa and Pike, 2005). Peptidases are classified into 6 main groups based on the catalytic mechanism of the hydrolytic process: serine, aspartyl, metallo, threonine, and cysteine proteases, as well as peptidases with unknown mechanisms (Rawlings and Barrett, 1993; Barrett et al., 2004). Cysteine peptidases are characterized by the presence of a cysteine residue in the active site of the enzyme. The activity of this class of enzymes depends on the catalytic dyad formed by a cysteine and histidine residue. Cysteine peptidases are grouped into 5 clans of phylogenetically related proteins (CA, CD, CE, $\mathrm{CF}$, and $\mathrm{CH}$ ) (Rawlings and Barrett, 1993). The papain cysteine peptidase family exhibits an amino-terminal domain formed by an $\alpha$-helix and a carboxy-terminal domain with an anti-parallel $\beta$-sheet; it belongs to clan CA. This family is also made up of 11 lysosomal cysteine peptidases namely, cathepsins B, H, L, S, C, K, V, F, O, X, and W (Rawlings and Barrett, 1993; Turk et al., 2000; Barrett et al., 2004; Potempa and Pike, 2005). The aim of the present study was to report the recombinant expression, purification, and characterization of a cysteine peptidase from $X a c$, which may be involved in the pathogenicity of this bacterium, thereby constituting an interesting target for studies involving citrus canker disease and plant-pathogen interactions.

\section{MATERIAL AND METHODS}

\section{Strains and culture media}

Xac strain 306 was grown in nutrient broth medium ( $0.5 \%$ peptone and $0.3 \%$ beef extract) at $28^{\circ} \mathrm{C}$ for 3 days. The $\mathrm{KM} 71 \mathrm{H}$ strain of $P$. pastoris was grown in yeast extract peptone dextrose (YPD), agar medium (1.0\% yeast extract, $2.0 \%$ peptone, $2.0 \%$ dextrose, and $2.0 \%$ agar).

\section{Construction of expression plasmid}

The complete 813-bp coding region for the cysteine peptidase was amplified through polymerase chain reaction (PCR) using the primers Xac_EcoRI_F: 5'-CGGAATTCCATGAACACGCACCGTTCGCTC-3' and Xac_XbaI_R: 5'-CTCTAGAGCG TACACCACGTCGGCGCCGAT-3' and DNA from $X$. citri subsp citri 306 strain as the template. The primers were designed based on the sequence deposited in GenBank (accession No. AE008923, locus tag Xac 2853). The EcoRI and XbaI sites (underlined) were included in the primers for cleavage and insertion in the expression vector. For the amplification reaction, 20 ng template DNA, 1 U Taq DNA polymerase (Fermentas, Vilnius, Lithuania), 1X reaction buffer containing $10 \mathrm{mM}$ Tris- $\mathrm{HCl}, \mathrm{pH} 8.5$ and $50 \mathrm{mM} \mathrm{KCl}, 0.2 \mathrm{mM}$ deoxyribonucleotide triphosphate, and $1.5 \mathrm{mM} \mathrm{MgCl}_{2}$ were used. The amplification conditions were as follows: 
$95^{\circ} \mathrm{C}$ for $5 \mathrm{~min} ; 35$ cycles of $95^{\circ} \mathrm{C}$ for $45 \mathrm{~s}, 57^{\circ} \mathrm{C}$ for $45 \mathrm{~s}$, and $72^{\circ} \mathrm{C}$ for $1 \mathrm{~min}$, and finally $72^{\circ} \mathrm{C}$ for $10 \mathrm{~min}$ in a PTC- $100^{\mathrm{TM}} \mathrm{MJ}$ Research Thermocycler (Minnesota, USA). The PCR product was purified using the Wizard PCR Clean Up kit (Promega, Wisconsin, USA) and digested with restriction enzymes $E c o$ RI and $X b a I$. The fragment was ligated to the expression vector $\mathrm{pPICZ} \alpha \mathrm{C}$ (Invitrogen, New York, USA), previously digested with the same enzymes, and the reaction was used to transform Escherichia coli DH5 $\alpha$ competent cells obtained through treatment with calcium chloride (Sambrook and Russell, 2001). The recombinant clone pPICZaC CPXAC was selected and sequenced using the dideoxy method in a MegaBace $^{\mathrm{TM}} 1000$ DNA sequencer (GE Healthcare, Uppsala, Sweden) (Sanger et al., 1977). The recombinant clone was linearized with the restriction enzyme PmeI (Invitrogen), and the DNA was transformed into P. pastoris strain KM71H competent cells through electroporation using a Bio-Rad GenePulser II. The clone selection was performed in YPD medium containing $100 \mu \mathrm{g} / \mathrm{mL}$ bleomycin/phleomycin (Zeocin, Invitrogen) antibiotic at $30^{\circ} \mathrm{C}$ for 310 days.

\section{Expression of ${ }_{\text {HIS }}$ CPXAC protein}

The $\mathrm{KM} 71 \mathrm{H}{ }_{H I S} \mathrm{CPXAC}$ clone was selected and grown in $10 \mathrm{~mL}$ buffered complex glycerol medium (1.0\% yeast extract, $2.0 \%$ peptone, $100 \mathrm{mM}$ potassium phosphate, $\mathrm{pH} 6.0$, $1.34 \%$ yeast nitrogen base, $4 \times 10^{-5 \%}$ biotin, and $1.0 \%$ glycerol) for $24 \mathrm{~h}$ at $30^{\circ} \mathrm{C}$ and 250 $\mathrm{rpm}$. The overnight culture was used to inoculate $500 \mathrm{~mL}$ buffered complex glycerol medium, which was maintained at $30^{\circ} \mathrm{C}$ and $250 \mathrm{rpm}$ until reaching an optical density of 6.0 at $600 \mathrm{~nm}$ $\left(\mathrm{OD}_{600 \mathrm{~mm}}\right)$. The cells were centrifuged at $3000 \mathrm{~g}$ for $5 \mathrm{~min}$ at room temperature. For the expression assays, the cells were resuspended in buffered methanol complex medium $(1.0 \%$ yeast extract, $2.0 \%$ peptone, $100 \mathrm{mM}$ potassium phosphate, $\mathrm{pH} 6.0,1.34 \%$ yeast nitrogen base, $4 \mathrm{x}$ $10^{-5 \%}$ biotin, and $0.5 \%$ methanol) in a final volume of $100 \mathrm{~mL}$. The bottle culture was incubated at $30^{\circ} \mathrm{C}$ and $250 \mathrm{rpm}$ for $48 \mathrm{~h}$. The culture was supplemented with $100 \%$ methanol every $24 \mathrm{~h}$ to maintain a final concentration at $0.5 \%(\mathrm{v} / \mathrm{v})$.

\section{Purification of ${ }_{H I S}$ CPXAC protein}

Yeast cells expressing ${ }_{\text {HIS }}$ CPXAC protein were centrifuged at $3000 \mathrm{~g}$ for $5 \mathrm{~min}$. Supernatant containing the secreted ${ }_{H I S} \mathrm{CPXAC}$ protein was passed through a $0.45-\mu \mathrm{m}$ filter, and the protein was purified with affinity chromatography in a nickel column Ni-NTA Superflow (Qiagen, Düsseldorf, Germany). The column was equilibrated with buffer containing $10 \mathrm{mM}$ Tris- $\mathrm{HCl}, 100 \mathrm{mM} \mathrm{NaCl}$, and $50 \mathrm{mM} \mathrm{NaH}_{2} \mathrm{PO}_{4}, \mathrm{pH} 8.0$, and the protein was eluted with the same buffer containing increasing imidazole concentrations $(10,25,50,75,100$, and 250 $\mathrm{mM})$. The purified protein was analyzed by $15 \%$ sodium dodecyl sulfate polyacrylamide gel electrophoresis (SDS-PAGE) (Laemmli, 1970), and the fractions containing the protein were dialyzed using molecular weight cutoff: 14,000 membranes (Spectrum Laboratories, California, USA) in $100 \mathrm{mM}$ sodium acetate buffer, $\mathrm{pH}$ 5.0. The concentration was determined using the bicinchoninic acid method (Smith et al., 1985).

\section{Western immunoblotting}

Polyclonal antibodies were produced using an insoluble ${ }_{H I S}$ CPXAC expressed in $E$. 
coli Rosetta (data not shown), which was excised and eluted with SDS-PAGE. Standard procedures were followed for the production of antibodies (Sambrook and Russell, 2001). Approximately $50 \mu \mathrm{g}$ eluted protein was inoculated into mice with Freund's complete adjuvant (Sigma, Missouri, USA), which is responsible for the primary immune response. After 45 days, the same amount of protein was inoculated, this time with Freud's incomplete adjuvant (Sigma), which is responsible for the secondary immune response. After 15 days, the immunized animals were bled, and the serum was collected by centrifugation at 15,700 $\mathrm{g}$ for $5 \mathrm{~min}$ and maintained at $4{ }^{\circ} \mathrm{C}$. For Western blotting, the recombinant protein was subjected to $15 \%$ SDS-PAGE and transferred to a polyvinylidene fluoride (PVDF) membrane (Invitrogen) via electroblotting in buffer containing $200 \mathrm{mM}$ Tris- $\mathrm{HCl}, 50 \mathrm{mM}$ glycine, and $20 \%$ methanol. The membrane was incubated for $1 \mathrm{~h}$ in a blocking buffer, washed with phosphate-buffered saline (100 mM Tris, $70 \mathrm{mM} \mathrm{NaCl}, \mathrm{pH} 8.0)$, incubated with anti- ${ }_{\text {HIS }}$ CPXAC antibody (1:15.000) for $90 \mathrm{~min}$, and washed as described above. The membrane was then incubated with anti-mouse immunoglobulin $\mathrm{G}$ alkaline phosphatase (Sigma) for $90 \mathrm{~min}$, washed with phosphate-buffered saline, and revealed with nitroblue tetrazolium-5-bromo-4-chloro-3-indolyl-phosphate substrate for alkaline phosphatase (Pierce, Illinois, USA).

\section{Activation of ${ }_{H I S}$ CPXAC enzyme}

The activation of the recombinant enzyme was performed using a method described by Brömme et al. (2004) with modifications. The enzyme was incubated in $100 \mathrm{mM}$ sodium acetate buffer, $\mathrm{pH} 4.5$, in the presence of $5 \mathrm{mM}$ dithiothreitol (DTT, ICN Biomedicals Inc., USA) at $37^{\circ} \mathrm{C}$ for $30 \mathrm{~min}$ and maintained at room temperature for $6 \mathrm{~h}$.

\section{Protein sequencing}

The ${ }_{H I S}$ CPXAC protein was subjected to $15 \%$ SDS-PAGE and transferred to a PVDF membrane via electroblotting. The membrane was stained with Ponceau solution $(0.1 \mathrm{~g}$ Ponceau dye, $1.0 \%$ acetic acid) for $1 \mathrm{~min}$ and washed with distilled water for $3 \mathrm{~min}$. The protein on the PVDF membrane was excised and analyzed in a protein sequencer (PPSQ-23A Shimadzu) following the manufacturer procedure.

\section{Assays of ${ }_{H I S}$ CPXAC catalytic activity}

The enzyme activity of ${ }_{H I S}$ CPXAC cysteine peptidase was continuously followed using a Hitachi F-2500 spectrofluorometer by measuring the fluorescence at $\lambda_{\mathrm{ex}}=380$ and $\lambda_{\mathrm{em}}=460$ $\mathrm{nm}$ based on a procedure described by Anastasi et al. (1983). The concentration of the cysteine peptidase was determined with active site titration using the E-64 inhibitor based on a procedure described by Barrett and Kirschke (1981). The purified enzyme was added to $100 \mathrm{mM}$ sodium acetate buffer, $\mathrm{pH} 5.5$, containing $2.5 \mathrm{mM}$ DTT $(1.0 \mathrm{~mL}$ final volume) and incubated for $3 \mathrm{~min}$ at $30^{\circ} \mathrm{C}$. The fluorogenic substrates carbobenzoxy (Z)-Phe-Arg-methylcoumarin (MCA), Z-ArgArg-MCA, and Z-Leu-Arg-MCA (Calbiochem, La Jolla, CA, USA) were then added in various concentrations, and enzyme activity was monitored. The apparent second-order rate constant $k_{\text {cal }}$ $K_{\mathrm{m}}$ was determined under pseudo-first-order conditions in which [S] $<K_{\mathrm{m}}$ and calculated with nonlinear regression using the GraFit program (Staines, UK) (Leatherbarrow, 1992). 


\section{Inhibition of enzyme activity}

The inhibition of cysteine peptidase activity was determined spectrofluorometrically using the fluorogenic substrate Z-Leu-Arg-7-amido-4-MCA (Calbiochem) based on procedure described by Anastasi et al. (1983). Fluorescence was measured in a Hitachi F-2500 spectrofluorometer at $\lambda_{\mathrm{ex}}=380$ and $\lambda_{\mathrm{em}}=460 \mathrm{~nm}$. Inhibitory activity was determined by measuring the residual hydrolytic activity of cysteine peptidase. The enzyme was added to $100 \mathrm{mM}$ sodium acetate buffer, $\mathrm{pH} 5.5$, containing $2.5 \mathrm{mM}$ DTT (final volume, $1.0 \mathrm{~mL}$ ) and subsequent incubations at $30^{\circ} \mathrm{C}$ were performed with cysteine peptidase inhibitors CaneCPI-1 (Soares-Costa et al., 2002), CaneCPI-2, CaneCPI-3 (Gianotti et al., 2006), CaneCPI-4 (Gianotti et al., 2008), and E-64. Z-Leu-Arg-MCA (0.05 mM) was then added, and residual cysteine peptidase activity was determined. The inhibition constant $\left(\mathrm{K}_{\mathrm{i}}\right)$ was calculated following Morrison's procedure using the GraFit program (Leatherbarrow, 1992).

\section{Optimal pH assay}

Optimal pH for enzyme activity was determined at $30^{\circ} \mathrm{C}$ using $0.05 \mu \mathrm{M}$ Z-Leu-ArgMCA as the substrate and the following buffers: $100 \mathrm{mM}$ sodium acetate, $\mathrm{pH} 3.0-5.5 ; 100 \mathrm{mM}$ sodium phosphate, $\mathrm{pH}$ 6.0-7.0, and $100 \mathrm{mM}$ Tris-HCl, $\mathrm{pH}$ 7.5-8.0.

\section{Optimal temperature}

Enzyme activity of ${ }_{H I S} \mathrm{CPXAC}$ cysteine peptidase at various temperatures $\left(10^{\circ}\right.$, $15^{\circ}, 20^{\circ}, 25^{\circ}, 30^{\circ}, 35^{\circ}$, and $40^{\circ} \mathrm{C}$ ) was continuously followed in a Hitachi F-2500 spectrofluorometer by measuring fluorescence at $\lambda_{\mathrm{ex}}=380$ and $\lambda_{\mathrm{em}}=460 \mathrm{~nm}$ with Z-LeuArg-MCA as the substrate in $100 \mathrm{mM}$ sodium acetate buffer, $\mathrm{pH} 5.5$, containing $2.5 \mathrm{mM}$ DTT (final volume, $1.0 \mathrm{~mL}$ ). The ${ }_{H I S} \mathrm{CPXAC}$ temperature test was performed at various temperatures, and the remaining activity of the cysteine peptidases was measured (Nagamori et al., 1990).

\section{Identification of native CPXAC secreted by Xac in pathogenicity-inducing medium}

Bacterial strain 306 of Xac was grown overnight in nutrient broth medium $(5 \mathrm{~g} / \mathrm{L}$ peptone and $3 \mathrm{~g} / \mathrm{L}$ beef extract) at $28^{\circ} \mathrm{C}$ until it reached an $\mathrm{OD}_{600 \mathrm{~nm}}$ of 0.8 . The cell mass was collected via centrifugation and resuspended in XAM1 medium [a pathogenicityinducing medium made up of nutrient broth medium and $7.57 \mathrm{mM}\left(\mathrm{NH}_{4}\right)_{2} \mathrm{SO}_{4}, 33 \mathrm{mM}$ $\mathrm{KH}_{2} \mathrm{PO}_{4}, 60.28 \mathrm{mM} \mathrm{K}_{2} \mathrm{HPO}_{4}, 1.7 \mathrm{mM}$ sodium citrate, $1 \mathrm{M} \mathrm{MgSO}_{4}, 0.03 \%$ casamino acids, $10 \mathrm{mM}$ fructose, $10 \mathrm{mM}$ sucrose, and $1 \mathrm{mg} / \mathrm{mL}$ bovine serum albumin, $\mathrm{pH} 5.4], 1 \mathrm{mg} / \mathrm{mL}$ bovine serum albumin, $\mathrm{pH}$ 5.4, following a method described by Wengelnik et al. (1996) and modified by Carvalho (2006) and maintained at $28^{\circ} \mathrm{C}$ overnight until it reached an $\mathrm{OD}_{600 \mathrm{~nm}}$ of 1.0. The secreted proteins in the supernatant of both media were precipitated with trichloroacetic acid at a final concentration of $10 \%$ and washed twice with $80 \%$ acetone. The samples were analyzed using 15\% SDS-PAGE and subjected to immunoblotting analyses using anti-CPXAC antibody. 


\section{RESULTS}

\section{In silico analysis of cysteine peptidase (open reading frame $\mathrm{XAC2853)}$}

The annotation of the genome of Xac strain 306 identified an open reading frame that coded for a possible cysteine peptidase of 813 bp (GenBank accession No. AE008923, locus tag, Xac 2853) (Da Silva et al., 2002). The sequence encoded a predicted protein of 270 -amino acid residues with a molecular weight of approximately $28.6 \mathrm{kDa}$. According to the predictions of the Signal P 3.0 program (Nielsen and Krogh, 1998), the sequence has a probable signal peptide at positions 1-24. The amino acid sequence of cysteine peptidase from Xac exhibits a conserved domain formed by the catalytic dyad $\mathrm{Cys}^{75}$ and $\mathrm{His}^{224}$ flanked by amino acid residues $\mathrm{Gln}^{69}$ and $\mathrm{Asn}^{240}$, which are important for the correct conformation of the catalytic site of the mature protein (Barrett et al., 2004; Potempa and Pike, 2005). These characteristics together allow the inclusion of CPXAC in the $\mathrm{C} 1$ family of cysteine peptidases (Rawlings and Barrett, 1993).

The alignment in Figure 1 shows that the cysteine peptidase from Xac is similar to those of other phytopathogenic organisms such as $X$. vesicatoria ( $80 \%$ similarity), which is the causal agent of bacterial spot disease in tomatoes and peppers (Thieme et al., 2005). This high degree of similarity was expected, as both organisms belong to the family Xanthomonadaceae. The sequence of cysteine peptidase from Xac is also similar to that of Pseudomonas syringae ( $76 \%$ similarity), which causes leaf spot disease on tomato plants (Hirano and Upper, 2000); a cysteine peptidase from the bacterium Xylella fastidiosa (72\% similarity), which is responsible for citrus variegated chlorosis (Nogaroto et al., 2006); and to a cysteine peptidase from X. oryzae (70\% similarity), which is the causal agent of bacterial leaf blight in rice (Furutani et al., 2004). With the exception of the sequence from $X$. fastidiosa, which has been studied by Nogaroto et al. (2006), the translation initiation sites of all sequences used in the alignment of Figure 1 were verified only with genome annotation.

\section{Recombinant expression and purification of ${ }_{H I S} \mathrm{CPXAC}$}

The recombinant protein ${ }_{H I S} \mathrm{CPXAC}$ was expressed in $P$. pastoris $(\mathrm{KM} 71 \mathrm{H})$ after 48 $\mathrm{h}$ of induction, and as expected, it was secreted into the extracellular environment owing to the presence of secretion factor signal $\alpha$ coded by the plasmid pPICZ $\alpha$ C. SDS-PAGE analysis demonstrated the presence of a band with a molecular mass of $31.2 \mathrm{kDa}$, which corresponded to the His-tagged cysteine peptidase in Xac (Figure 2A). The purification of the enzyme was performed directly through affinity chromatography on a nickel column, and the protein was eluted with $250 \mathrm{mM}$ imidazole buffer. The purification system was efficient, as SDS-PAGE analysis revealed the presence of a single band of approximately $31.2 \mathrm{kDa}$ corresponding to ${ }_{H I S} \mathrm{CPXAC}$ (Figure 2B).

The yield of ${ }_{H I S}$ CPXAC-purified protein was approximately $10 \mathrm{mg} / \mathrm{L}$ culture. Western blot analysis revealed that the polyclonal mouse antibody produced in mice against the recombinant ${ }_{H I S} \mathrm{CPXAC}$ detected the secreted protein from P. pastoris, as well as the purified protein from affinity chromatography (Figure $2 \mathrm{C}$ ). These results confirmed the authenticity of the protein, because the antibody was produced using ${ }_{H I S} \mathrm{CPXAC}$ produced in bacteria. 

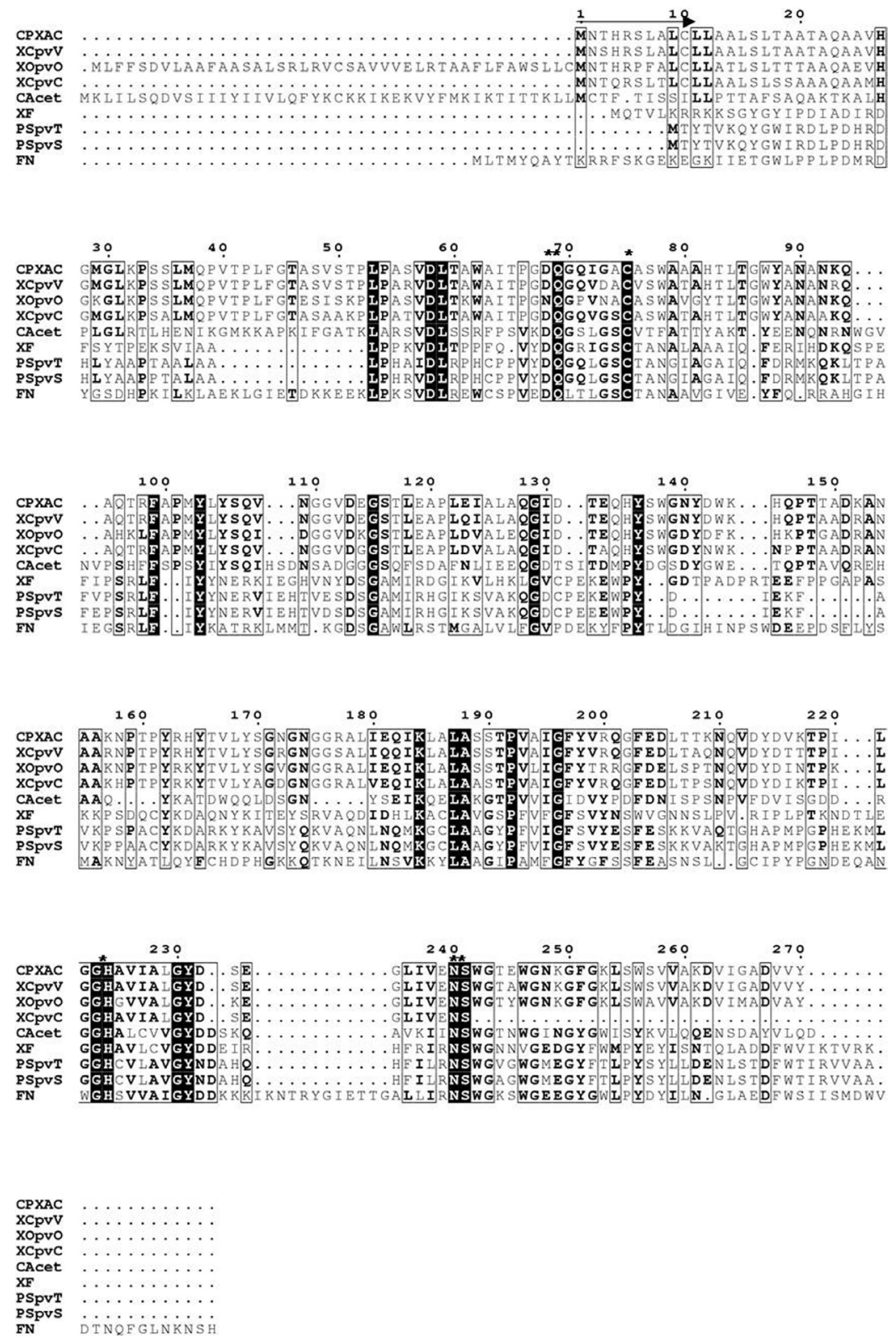

Figure 1. Alignment between cysteine peptidase from Xanthomonas citri subsp citri (CPXAC) and other cysteine peptidases. Alignment was performed with cysteine peptidase from CPXAC and others from $X$. vesicatoria (XCpvV), X. oryzae (XOpvO), X. campestris (XCpvC), Clostridium acetobutylicum (CAcet), Xylella fastidiosa $9 a 5 c$ (XF), Pseudomonas syringae str. DC3000 (PSpvT), P. syringae strain B728a (PSpvS) and Fusobacterium nucleatum subsp nucleatum ATCC 25586 (FN). Arrow indicates region corresponding to probable signal peptide, as indicated by the Signal P 3.0 program. *Residues belonging to catalytic dyad. **Amino acid residues flanking catalytic site. Black boxes correspond to regions conserved between proteins with $100 \%$ identity. Open boxes correspond to 50 to $90 \%$ identity. Amino acids with greater than $90 \%$ identity are in bold type. 
A

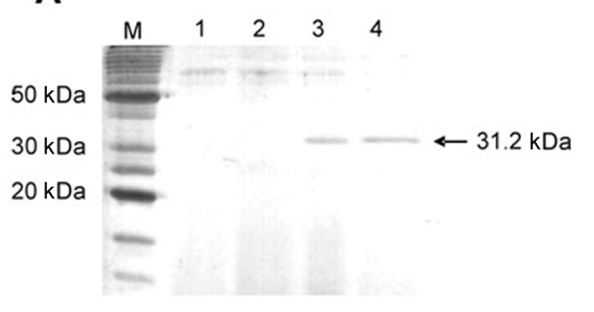

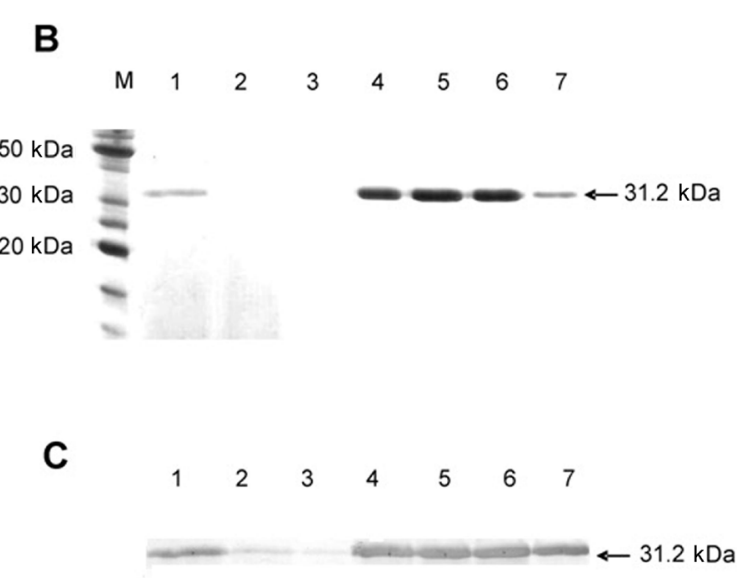

Figure 2. Analysis of ${ }_{H I S}$ CPXAC expression in Pichia pastoris, purification and immunodetection assay. A. SDSPAGE $15 \%$ stained with Coomassie blue, showing induction of ${ }_{H I S} \mathrm{CPXAC}$ by $0.5 \%$ methanol: lane $M=$ molecular mass marker; lane $1=$ supernatant at $0 \mathrm{~h}$ of induction; lane $2=$ supernatant at $24 \mathrm{~h}$ of induction; lane $3=$ supernatant at $48 \mathrm{~h}$ of induction; lane $4=$ supernatant at $72 \mathrm{~h}$ of induction; B. SDS-PAGE (15\%) stained with Coomassie blue, showing induction and subsequent purification of ${ }_{H I S} \mathrm{CPXAC}$ by affinity chromatography in nickel column: lane $M$ $=$ molecular mass marker; lane $1=$ supernatant at $48 \mathrm{~h}$ of induction; lane $2=$ washing; lane $3=$ flow through 1 ; lane $4=$ protein elution in $75 \mathrm{mM}$ imidazole; lane $5=$ protein elution in $100 \mathrm{mM}$ imidazole; lane $6=$ protein elution in $100 \mathrm{mM}$ imidazole; lane 7 = protein elution in $250 \mathrm{mM}$ imidazole; $\mathbf{C}$. immunoblotting assay performed with the same sample described above.

\section{Activation of the ${ }_{H I S} C P X A C$ protein}

The activation of cysteine peptidases is generally necessary to remove the probable proregion from the enzyme. The ${ }_{H I S} \mathrm{CPXAC}$ was autocatalytically activated in the presence of $100 \mathrm{mM}$ sodium acetate, $\mathrm{pH} 4.5$, with $5 \mathrm{mM}$ DTT as the reducing agent.

\section{Protein sequencing}

To confirm the authenticity of the protein expressed in P. pastoris and identify the signal peptide cleavage point, we performed $\mathrm{N}$-terminal sequencing of purified ${ }_{H I S} \mathrm{CPXAC}$ after activation. The $\mathrm{N}$-terminal region of the ${ }_{H I S} \mathrm{CPXAC}$ recombinant protein displayed the initial region AVHGM starting from the 25th amino acid residue. This result agreed with the prediction made by the Signal P 3.0 program (Nielsen and Krogh, 1998), which indicated a putative signal peptide from amino acid residues 1-24 (MNTHRSLALCLLAALSLTAATAQA).

\section{Assay of ${ }_{H I S}$ CPXAC catalytic activity}

The catalytic efficiency $\left(k_{\text {cat }} / K_{\mathrm{m}}\right)$ of the cysteine peptidase ${ }_{H I S} \mathrm{CPXAC}$ was determined using Z-Leu-Arg-MCA, Z-Phe-Arg-MCA, and Z-Arg-Arg-MCA as substrates. The $k_{\text {cat }} / K_{\mathrm{m}}$ value for the hydrolysis of Z-Leu-Arg-MCA was $47 \mu \mathrm{M}^{-1} \cdot \mathrm{s}^{-1}$. The other substrates were not hydrolyzed by ${ }_{H I S} \mathrm{CPXAC}$. 


\section{Inhibition activity assay}

${ }_{H I S} \mathrm{CPXAC}$ was assayed in the presence of the synthetic inhibitor E-64 [trans-epoxysuccinyl-L-leucylamido-(4-guanidino) butane] and recombinant cysteine peptidase inhibitors from sugarcane: CaneCPI-1 (Soares-Costa et al., 2002), CaneCPI-2, CaneCPI-3 (Gianotti et al., 2006), and Cane-CPI-4 (Gianotti et al., 2008). These recombinant cystatins inhibited the activity of cysteine peptidase with constant inhibition $\left(\mathrm{K}_{\mathrm{i}}\right)$ in nanomolar order (Table 1). E-64 inhibited the cysteine peptidase with a $\mathrm{K}_{\mathrm{i}}$ of $1.214 \mathrm{nM}$. CaneCPI-1, CaneCPI-2, CaneCPI-3, and CaneCPI-4 achieved $\mathrm{K}_{\mathrm{i}}$ values of 84.64, 0.09, 0.09, and $0.012 \mathrm{nM}$, respectively (see Table 1).

\begin{tabular}{|c|c|}
\hline Inhibitor & $\mathrm{K}_{\mathrm{i}}(\mathrm{nM})$ \\
\hline $\begin{array}{l}\text { E-64 } \\
\text { CaneCPI-1 }\end{array}$ & $\begin{array}{l}1.2 \pm 0.2 \\
84 \pm 2\end{array}$ \\
\hline CaneCPI-2 & $0.09 \pm 0.02$ \\
\hline CaneCPI-3 & $0.09 \pm 0.02$ \\
\hline CaneCPI-4 & $0.012 \pm 0.003$ \\
\hline
\end{tabular}

\section{Optimal pH assay}

The optimal $\mathrm{pH}$ value for enzyme activity was determined using Z-Leu-Arg-MCA as a substrate. The best $\mathrm{pH}$ for ${ }_{\text {HIS }} \mathrm{CPXAC}$ was 5.5 (100\% activity). At $\mathrm{pH}$ values of 4.5 and 6.5 , the enzyme exhibited approximately $60 \%$ activity (Figure 3 ).

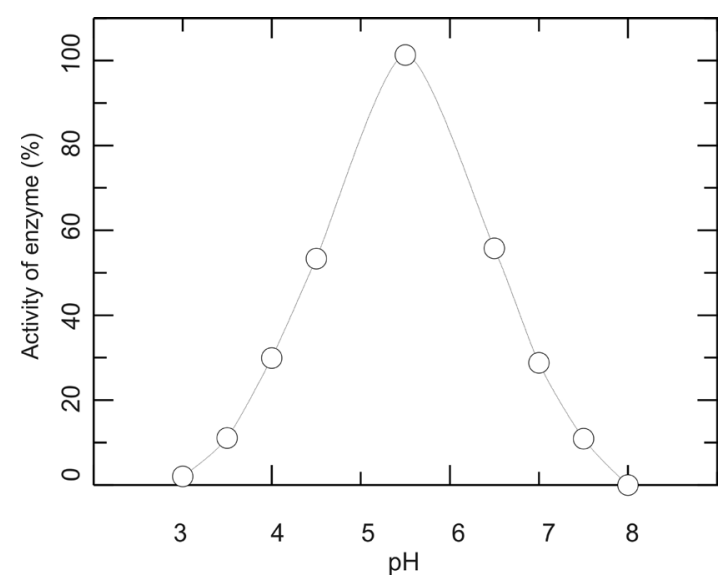

Figure 3. Profile of ${ }_{H I S} \mathrm{CPXAC}$ activity with $\mathrm{pH}$ variation; assays performed using Z-Leu-Arg-MCA as substrate; hydrolytic activity of enzyme measured in buffers $100 \mathrm{mM}$ sodium acetate, $\mathrm{pH} 3.0-5.5$, disodium phosphate, $\mathrm{pH}$ 6.0-7.0 and Tris-HCl, $\mathrm{pH}$ 7.5-8.0.

\section{Optimal temperature}

Enzyme activity of ${ }_{H I S} \mathrm{CPXAC}$ was measured at temperatures ranging from $10^{\circ}$ to 
$40^{\circ} \mathrm{C}$. As illustrated in Figure 4, the optimal temperature for ${ }_{H I S} \mathrm{CPXAC}$ activity was $30^{\circ} \mathrm{C}$. A significant loss of enzyme activity was detected at temperatures of $10^{\circ}, 20^{\circ}$, and $40^{\circ} \mathrm{C}$.

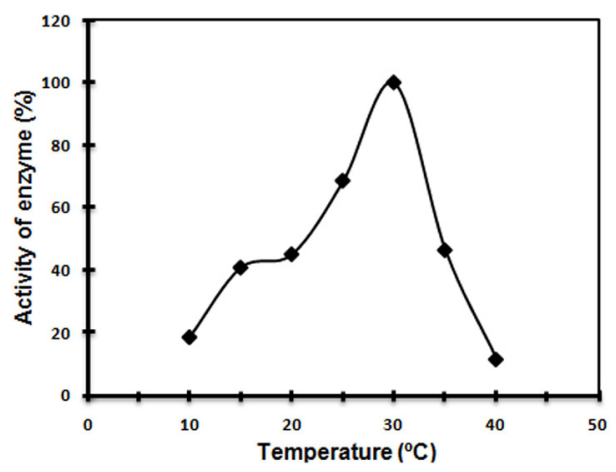

Figure 4. Optimal temperature assays of ${ }_{H I S} \mathrm{CPXAC}$; Z-Leu-Arg-MCA used as fluorogenic substrate; incubations performed in $100 \mathrm{mM}$ sodium acetate buffer, $\mathrm{pH} 5.5$, with $2.5 \mathrm{mM}$ dithiothreitol; assay performed at $10^{\circ}, 15^{\circ}, 20^{\circ}$, $25^{\circ}, 30^{\circ}, 35^{\circ}$, and $40^{\circ} \mathrm{C}$; graphic shows optimal temperature curve of enzyme (squares).

\section{Identification of CPXAC secreted by Xac in pathogenicity-inducing medium}

An experiment was performed to determine whether the CPXAC protein from Xac strain 306 could be secreted in extracellular medium and whether this secretion was induced. The samples were analyzed using SDS-PAGE and Western blotting. The negative control was pathogenicity-inducing XAM1 medium to demonstrate that the antibody does not recognize any protein in the medium (Figure 5 , lane 3 ). The anti- ${ }_{H I S}$ CPXAC antibody detected cysteine peptidase in the $X a c$ culture when the bacterium was grown in XAM1, whereas the cysteine peptidase was not detected when $X a c$ was cultivated in the nutrient broth medium, which is not pathogenicity inducing (see Figure 5).

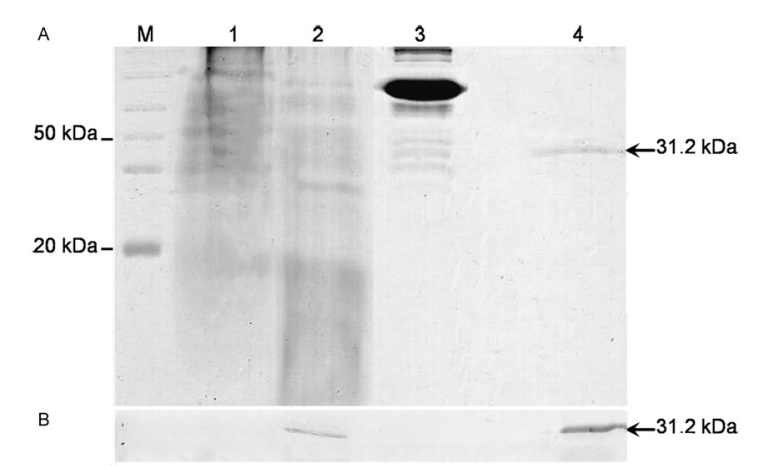

Figure 5. Cysteine peptidase expression in Xanthomonas citri subsp citri during pathogenicity induction. A. SDS-PAGE (15\%) stained with Coomassie blue, showing expressed proteins in extracellular medium; lane $M$ $=$ molecular mass marker; lane $1=X . c$. subsp citri wild strain grown in nutrient broth medium; lane $2=X . c$. subsp citri wild strain grown in XAM1 medium; lane 3 = negative control (XAM1 medium) to demonstrate that the antibody does not recognize any protein in the medium; lane $4=$ recombinant ${ }_{H I S}$ CPXAC-purified protein. B. Immunodetection assay performed with the same samples described above. 


\section{DISCUSSION}

The present study reports the heterologous expression, purification, and characterization of a cysteine peptidase from strain 306 of the bacterium Xac in P. pastoris. The choice of P. pastoris as a host for expression was made after an intensive effort to express it in E. coli, which did not produce a soluble protein (data not shown). The yield of ${ }_{H I S}$ CPXAC purified from P. pastoris was approximately $10 \mathrm{mg} / \mathrm{L}$ culture, which was sufficient to perform all experiments for enzyme characterization. SDS-PAGE analysis demonstrated the presence of a band with a molecular mass of $31.2 \mathrm{kDa}$, which matches the predicted cysteine peptidase from Xac fused with the His-tag and indicates the absence of the ${ }_{H I S}$ CPXAC protein glycosylation in this eukaryotic host.

The polyclonal anti- ${ }_{H S} \mathrm{CPXAC}$ antibody detected the recombinant protein with an expected molecular mass of $31.2 \mathrm{kDa}$ by Western blotting, demonstrating that the polyclonal antibody is specific. This anti- ${ }_{H I S} \mathrm{CPXAC}$ antibody recognized the cysteine peptidase in the supernatant of an Xac culture in XAM1 medium (pathogenicity inducing) but did not recognize the protein in nutrient broth medium, indicating that the expression of cysteine peptidase is not required when the bacteria grows in nutrient-rich conditions but seems to be important for infection. This case displayed an increased expression of genes related to pathogenicity, suggesting the possible involvement of cysteine peptidase in that process. Proteins expressed in XAM1 medium are regulated by genes such as $h r p$, which are associated with pathogenicity. The regulation of $h r p$ genes might be influenced by plant-inducing factors that occur owing to the presence of a plant-inducible promoter known as PIP box [TTCGC $\left(\mathrm{N}_{15}\right)$ TTCGC], as well as the nutritional conditions of the medium (Leach and White, 1996; Da Silva et al., 2002). Yamazaki et al. (2008) have suggested the presence of an imperfect PIP box for the CPXAC gene. By contrast, pathogenicity genes $h r p X$ and $h r p G$ are responsible for the secretion of proteins in type III and some type II systems (Sandkvist, 2001; Furutani et al., 2004). Furthermore, a functional interplay between both secretion systems has been suggested (Büttner and Bonas, 2010). These findings indicated that CPXAC could be induced by $h r p \mathrm{X}$ and $h r p \mathrm{G}$ and corroborated its possible participation in Xac infection.

Activation of the ${ }_{H I S}$ CPXAC protein was performed in acid conditions, which allowed the processing of the proenzyme. Once the proenzyme is activated, autoproteolytic cleavage occurs, and the mature protein can process other precursor molecules, leading to a chain reaction that allows the removal of the proregion from the immature enzyme (Brömme et al., 2004). At $\mathrm{pH}$ values of 4.5 and 6.5 , the enzyme exhibited approximately $60 \%$ activity.

The sequencing of the $\mathrm{N}$-terminus in the ${ }_{H I S} \mathrm{CPXAC}$ protein revealed the presence of a signal peptide, which is an intrinsic characteristic of proteins belonging to a type II secretion system. This system is common in Gram-negative bacteria, and the secretion process occurs in two steps. Initially, the secretion machinery translocates the protein across the inner membrane via a translocase enzyme to the periplasm and then transports it to the outer membrane via a type II secretion system (Sandkvist, 2001; Brunings and Gabriel, 2003).

The secretion products from Xac have been described by Yamazaki et al. (2008), who reported the presence of an extracellular cysteine peptidase secreted by Xac (strain NA-1) cultivated in medium that induced hrp and hypersensitivity genes. The $\mathrm{N}$-terminal region of this secreted cysteine peptidase was sequenced and generated AVHGMGLKPSSLMQPV, which is identical to the sequence from ${ }_{\text {HIS }}$ CPXAC (after the 25 th residue). This match was important for the identification and characterization of the target protein because it revealed the iden- 
tity of the N-terminal sequence of the authentic secretion product from Xanthomonas with CPXAC, suggesting the enzyme identified by Yamazaki et al. (2008) to be CPXAC.

Catalytic activity of the enzyme was observed only with the peptide Z-Leu-Arg-MCA, indicating that a hydrophobic aliphatic Leu residue in the $\mathrm{P}_{2}$ position is well accepted by the $\mathrm{S}_{2}$ subsite, which is a characteristic of some members of the papain family (Turk et al., 1998). Although most of the lysosomal cysteine proteases accept hydrophobic aromatic residue in the $\mathrm{P}_{2}$ position (Turk et al., 2000), ${ }_{H I S}$ CPXAC exhibits different behavior, as Z-Phe-Arg-MCA was not hydrolyzed by the enzyme. This preference for hydrophobic aliphatic substrates with a ramified lateral chain is an interesting characteristic of ${ }_{H I S} \mathrm{CPXAC}$, suggesting a restricted interaction of the substrate with the active site of the enzyme. The peptide Z-Arg-Arg-MCA was also resistant to hydrolysis, indicating that ${ }_{H I S} \mathrm{CPXAC}$ is not a cathepsin B-like enzyme (Hasnain et al., 1993).

Enzyme activity inhibition studies were performed using E-64, an irreversible inhibitor of cysteine peptidase, which inhibited enzyme activity considerably and provided further evidence that CPXAC is a cysteine peptidase (Bhattacharya et al., 2001). The inhibitory effect of cystatins was also investigated. These potent inhibitors of papain-like cysteine proteinases bind adjacent to the protease active site, obstructing access to the substrate (Martinez et al., 2007). Among the inhibitors tested, the sugarcane cystatin CaneCPI-4 proved to be the most effective inhibitor of ${ }_{\text {HIS }} \mathrm{CPXAC}$.

Infection by Xac and the development of citrus canker disease are generally negatively affected by low temperatures. Studies have shown that the optimal temperature for disease development is $25^{\circ}-30^{\circ} \mathrm{C}$ (Pruvost et al., 2002). ${ }_{H I S}$ CPXAC enzyme exhibited optimal activity at $30^{\circ} \mathrm{C}$, which agrees with the best temperature for infection. According to studies in subtropical environmental conditions, Xac cells remain viable for a long period around the lesion (latent form) at temperatures of approximately $20^{\circ} \mathrm{C}$; moreover, a rapid decline in bacterial population has been observed at low temperatures, which explains the minimal activity of the enzyme at $10^{\circ} \mathrm{C}$ (Pruvost et al., 2002; Dalla Pria et al., 2006). This information agrees with our observed data on ${ }_{H I S} \mathrm{CPXAC}$ activity at various temperatures.

In conclusion, the present study described the efficient expression of a cysteine peptidase from Xac in soluble form in P. pastoris and its characterization. CPXAC was expressed under induced conditions in the wild strain, thereby identifying it as a putative target for studies on plant-pathogen interactions, as well as the infection process in citrus canker and other diseases caused by Xanthomonas pathogens.

\section{ACKNOWLEDGMENTS}

Research supported by the Brazilian fostering agencies Fundo de Defesa da Citricultura and Fundação de Amparo à Pesquisa do Estado de São Paulo (Centro de Biotecnologia Molecular Estrutural/Centros de Pesquisa, Inovação e Difusão Proc. \#98/14138-2 and \#05/59833-5). The authors thank Dr. Heloísa Sobreiro S. Araújo of the Federal University of São Carlos for protein sequencing.

\section{REFERENCES}

Anastasi A, Brown MA, Kembhavi AA, Nicklin MJ, et al. (1983). Cystatin, a protein inhibitor of cysteine proteinases. Improved purification from egg white, characterization, and detection in chicken serum. Biochem. J. 211: 129-138. 
Barrett AJ and Kirschke H (1981). Cathepsin B, Cathepsin H, and cathepsin L. Methods Enzymol. 80 Pt C: 535-561.

Barrett AJ, Rawlings ND and Woessner JF (2004). Handbook of Proteolytic Enzymes. 2nd edn. Elsevier Academic Press, London.

Bhattacharya S, Ghosh S, Chakraborty S, Bera AK, et al. (2001). Insight to structural subsite recognition in plant thiol protease-inhibitor complexes : understanding the basis of differential inhibition and the role of water. BMC Struct. Biol. 1: 4.

Brömme D, Nallaseth FS and Turk B (2004). Production and activation of recombinant papain-like cysteine proteases. Methods 32: 199-206.

Brunings AM and Gabriel DW (2003). Xanthomonas citri: breaking the surface. Mol. Plant Pathol. 4: 141-157.

Büttner D and Bonas U (2010). Regulation and secretion of Xanthomonas virulence factors. FEMS Microbiol. Rev. 34: 107-133.

Carvalho FMS (2006). Expressão Gênica em Xanthomonas axonopodis pv. citri Controlada por Promotores Induzidos pela Planta Hospedeira. Doctoral thesis, Faculdade de Medicina, Universidade de São Paulo, Ribeirão Preto.

Da Silva AC, Ferro JA, Reinach FC, Farah CS, et al. (2002). Comparison of the genomes of two Xanthomonas pathogens with differing host specificities. Nature 417: 459-463.

Dalla Pria M, Christiano RCS, Furtado EL, Amorim L, et al. (2006). Effect of temperature and leaf wetness duration on infection of sweet oranges by Asiatic citrus canker. Plant Pathol. 55: 657-663.

Furutani A, Tsuge S, Ohnishi K, Hikichi Y, et al. (2004). Evidence for HrpXo-dependent expression of type II secretory proteins in Xanthomonas oryzae pv. oryzae. J. Bacteriol. 186: 1374-1380.

Gabriel DW, Hunter JE, Kingsley MT, Miller JW, et al. (1988). Clonal population structure of Xanthomonas campestris and genetic diversity among citrus canker strains. Mol. Plant Microbe Interact. 2: 59-65.

Gianotti A, Rios WM, Soares-Costa A, Nogaroto V, et al. (2006). Recombinant expression, purification, and functional analysis of two novel cystatins from sugarcane (Saccharum officinarum). Protein Expr. Purif. 47: 483-489.

Gianotti A, Sommer CA, Carmona AK and Henrique-Silva F (2008). Inhibitory effect of the sugarcane cystatin CaneCPI-4 on cathepsins B and L and human breast cancer cell invasion. Biol. Chem. 389: 447-453.

Graham JH, Gottwald TR, Cubero J and Achor DS (2004). Xanthomonas axonopodis pv. citri: factors affecting successful eradication of citrus canker. Mol. Plant Pathol. 5: 1-15.

Hasnain S, Hirama T, Huber CP, Mason P, et al. (1993). Characterization of cathepsin B specificity by site-directed mutagenesis. Importance of Glu245 in the S2-P2 specificity for arginine and its role in transition state stabilization. J. Biol. Chem. 268: 235-240.

Hirano SS and Upper CD (2000). Bacteria in the leaf ecosystem with emphasis on Pseudomonas syringae-a pathogen, ice nucleus, and epiphyte. Microbiol. Mol. Biol. Rev. 64: 624-653.

Laemmli UK (1970). Cleavage of structural proteins during the assembly of the head of bacteriophage T4. Nature 227: 680-685.

Leach JE and White FF (1996). Bacterial avirulence genes. Annu Rev Phytopathol. 34: 153-179.

Leatherbarrow RJ (1992). Grafit, Version 5.0. Erithacus Software Ltd., Stains.

Martinez M, Diaz-Mendoza M, Carrillo L and Diaz I (2007). Carboxy terminal extended phytocystatins are bifunctional inhibitors of papain and legumain cysteine proteinases. FEBS Lett. 581: 2914-2918.

Moreira LM, de Souza RF, Digiampietri LA, Da Silva AC, et al. (2005). Comparative analyses of Xanthomonas and Xylella complete genomes. OMICS 9: 43-76.

Nagamori Y, Fujishima N and Okada S (1990). Purification and some properties of dipeptidyl carboxypeptidase from Bacillus pumilus. Agric. Biol. Chem. 54: 999-1005.

Nielsen H and Krogh A (1998). Prediction of Signal Peptides and Signal Anchors by a Hidden Markov Model. AAAI Press, California.

Nogaroto V, Tagliavini S, Gianotti A, Mikawa A, et al. (2006). Recombinant expression and characterization of a Xylella fastidiosa cysteine protease differentially expressed in a nonpathogenic strain. FEMS Microbiol. Lett. 261: 187-193.

Potempa J and Pike RN (2005). Bacterial Peptidases. In: Concepts in Bacterial Virulence (Russell W and Herwald H, eds.). Contrib. Microbiology Basel, Karger, 132-180.

Pruvost O, Boher B, Brocherieux C, Nicole M, et al. (2002). Survival of Xanthomonas axonopodis pv. citri in Leaf Lesions Under Tropical Environmental Conditions and Simulated Splash Dispersal of Inoculum. Phytopathology 92: 336-346.

Rawlings ND and Barrett AJ (1993). Evolutionary families of peptidases. Biochem. J. 290 (Pt 1): 205-218.

Sambrook J and Russell DW (2001). Molecular Cloning: A Laboratory Manual. 3rd edn. Cold Spring Harbor Laboratory Press, New York.

Sandkvist M (2001). Biology of type II secretion. Mol. Microbiol. 40: 271-283.

Sanger F, Nicklen S and Coulson AR (1977). DNA sequencing with chain-terminating inhibitors. Proc. Natl. Acad. Sci. U. S. A. 74: 5463-5467. 
Schubert TS and Miller JW (1996). Bacterial citrus canker. Plant Pathol. 377: 110-111.

Smith PK, Krohn RI, Hermanson GT, Mallia AK, et al. (1985). Measurement of protein using bicinchoninic acid. Anal. Biochem. 150: 76-85.

Soares-Costa A, Beltramini LM, Thiemann OH and Henrique-Silva F (2002). A sugarcane cystatin: recombinant expression, purification, and antifungal activity. Biochem. Biophys. Res. Commun. 296: 1194-1199.

Thieme F, Koebnik R, Bekel T, Berger C, et al. (2005). Insights into genome plasticity and pathogenicity of the plant pathogenic bacterium Xanthomonas campestris $p v$. vesicatoria revealed by the complete genome sequence. $J$. Bacteriol. 187: 7254-7266.

Turk B, Turk D and Turk V (2000). Lysosomal cysteine proteases: more than scavengers. Biochim. Biophys. Acta 1477: 98-111.

Turk D, Guncar G, Podobnik M and Turk B (1998). Revised definition of substrate binding sites of papain-like cysteine proteases. Biol. Chem. 379: 137-147.

Viegas F and Machado MA (2006). Câmara Setorial da Cadeia Produtiva da Citricultura. In: Contribuições das Câmaras Setoriais e Temáticas à Formulação de Políticas e Privadas para o Agronegócio. Ministério Agricultura e Abastecimento, 264-291.

Wengelnik K, Marie C, Russel M and Bonas U (1996). Expression and localization of HrpA1, a protein of Xanthomonas campestris $p v$. vesicatoria essential for pathogenicity and induction ofthe hypersensitive reaction. J. Bacteriol. 178: 1061-1069.

Yamazaki A, Hitara H and Tsuyumu S (2008). HrpG regulates type II secretory proteins in Xanthomonas axonopodis pv. citri. J. Gen. Plant Pathol. 74: 138-150. 